\title{
Response of Growth Parameters to Alternate Wetting and Drying Method of Water Management in Low Land Rice (Oryza sativa)
}

\author{
Kishor Mote ${ }^{1 *}$, V. Praveen Rao², V. Ramulu², K. Avil Kumar², \\ M. Uma Devi ${ }^{2}$ and S. Narender Reddy ${ }^{3}$ \\ ${ }^{1}$ Agronomy Division, Central Coffee Research Institute, Chikmagaluru -577117, \\ Karnataka, India \\ ${ }^{2}$ Water Technology Centre, Professor Jaysankar Telangana State Agriculture University, \\ Hyderabad-500030 India \\ ${ }^{3}$ Department of Crop Physiology, Professor Jaysankar Telangana State Agriculture University, \\ Hyderabad-500030 India \\ *Corresponding author:
}

\begin{tabular}{|c|c|}
\hline & A B S T R A $\mathbf{C}$ \\
\hline & $\begin{array}{l}\text { A study was conducted with the objective to study the comparative performance of rice in } \\
\text { terms of growth under continuous submergence and Alternate wetting and drying (AWD) } \\
\text { water management practice. The treatments consisted of continuous submergence } \\
\text { throughout the crop growing season besides AWD irrigation regimes with two ponded } \\
\text { water depths of } 3 \text { and } 5 \mathrm{~cm} \text { and drop in ponded water levels in field water tube below }\end{array}$ \\
\hline Keywords & ground level to 5,10 and $15 \mathrm{~cm}$ depth. The eight treatments were laid out in randomized \\
\hline $\begin{array}{l}\text { Alternate Wetting } \\
\text { and Drying, } \\
\text { Lowland rice, } \\
\text { Growth parameters } \\
\text { and Field water } \\
\text { tube. }\end{array}$ & $\begin{array}{l}\text { block design with three replications. Maintenance of Continuous Submergence depth of 3- } \\
\mathrm{cm} \text { from transplanting to PI and } 5-\mathrm{cm} \text { from PI to PM }\left(\mathrm{I}_{1}\right) \text { registered significantly superior } \\
\text { performance in terms of plant height }(106.8 \text { and } 107.8 \mathrm{~cm}) \text {, tiller production }(17.9 \text { and } \\
\left.\left.19.5 \text { hill }^{-1}\right) \text {, LAI ( } 4.15 \text { and } 4.16\right) \text { and dry matter production }\left(54.04 \text { and } 56.37 \mathrm{~g} \mathrm{hill}^{-1}\right) \text { in } \\
2013 \text { and } 2014 \text {, respectively over rest of the irrigation regimes except that it was on par } \\
\text { with } \mathrm{I}_{2} \text { (Flooding to a water depth of } 3-\mathrm{cm} \text { between } 15 \text { DAT to PM as and when ponded }\end{array}$ \\
\hline Article Info & $\begin{array}{l}\text { water level drops to } 5-\mathrm{cm} \text { BGL in field water tube), } \mathrm{I}_{5} \text { (Flooding to a water depth of } 5-\mathrm{cm} \\
\text { between } 15 \mathrm{DAT} \text { to } \mathrm{PM} \text { as and when ponded water level drops to } 5-\mathrm{cm} \text { BGL in field water }\end{array}$ \\
\hline $\begin{array}{l}\text { Accepted: } \\
\text { 20 February } 2017 \\
\text { Available Online: } \\
10 \text { March } 2017\end{array}$ & $\begin{array}{l}\text { ponded water level drops to } 10-\mathrm{cm} \text { BGL in field water tube). Whereas, } \mathrm{I}_{4} \text { (Flooding to a } \\
\text { water depth of } 3-\mathrm{cm} \text { between } 15 \text { DAT to PM as and when ponded water level drops to } 15- \\
\mathrm{cm} \text { BGL in field water tube), } \mathrm{I}_{7} \text { (Flooding to a water depth of } 5-\mathrm{cm} \text { between } 15 \text { DAT to } \\
\mathrm{PM} \text { as and when ponded water level drops to } 15-\mathrm{cm} \text { BGL in field water tube) and } \mathrm{I}_{8}\end{array}$ \\
\hline & $\begin{array}{l}\text { (Flooding to a water depth of } 3-\mathrm{cm} \text { between } 15 \text { DAT to PI and } 5-\mathrm{cm} \text { between PI to PM as } \\
\text { and when ponded water level drops to } 15-\mathrm{cm} \text { BGL in field water tube) registered } \\
\text { significantly inferior performance in terms of plant height, tiller production, LAI and dry } \\
\text { matter production. So it can be concluded that rice crop can be successfully grown by } \\
\text { adopting an appropriate AWD irrigation regime under sandy clay soils of Rajendranagar, } \\
\text { Telangana State. }\end{array}$ \\
\hline
\end{tabular}

\section{Introduction}

A tremendous amount of water is used for the rice irrigation under the conventional water management in lowland rice termed as "continuous deep flooding irrigation" 
consuming about 70 to 80 per cent of the total irrigated fresh water resources in the major part of the rice growing regions in Asia including India (Bouman and Tuong, 2001).Reducing water input in rice production can have a high societal and environmental impact if the water saved can be diverted to areas where competition is high. A reduction of 10 per cent in water used in irrigated rice would free 150,000 million $\mathrm{m}^{3}$, corresponding to about 25 per cent of the total fresh water used globally for non-agricultural purposes (Klemm, 1999). However, rice is very sensitive to water stress. Attempts to reduce water in rice production may result in yield reduction and may threaten food security. The challenge is therefore to develop socially acceptable, economically viable and environmentally sustainable novel water management practice that allow rice production to be maintained or increased in the face of declining water availability.

There is a specific form of AWD called "Safe AWD' that has been developed to potentially reduce water inputs by about $30 \%$, while maintaining yields at the level of that of flooded rice (Bouman et al., 2007). In Safe AWD, the ponded water on the field (also called "perched water'") is allowed to drop to 15-20 cm below the soil surface before irrigation is applied. The depth of perched water is monitored using a perforated or punctured water tube embedded in the soil. With the threshold of 15-20 cm, roots are still able to extract water from the perched water table and no stress to the plants develops. In Safe AWD, each irrigation will flood the field to about $2-5 \mathrm{~cm}$ (in contrast to the $5-10 \mathrm{~cm}$ for traditional irrigation). During flowering, the field is kept flooded so as to avoid spikelet sterility. This specific AWD variant is the one typically used in the present study. In light of the concerns about irrigation water scarcity due to recurrent droughts in the area, the present experiment entitled "Standardization of Alternate Wetting and Drying (AWD) method of water management in low land rice (Oryza sativa (L.) for up scaling in command outlets" was conducted with the objective to study the comparative performance of rice in terms of growth under continuous submergence and AWD water management practice

\section{Materials and Methods}

The experiment was laid out in a randomized block design with eight irrigation regimes comprising of two submergence levels above the ground ( 3 and $5-\mathrm{cm}$ ) and three falling levels below ground surface $(5,10$ and $15-\mathrm{cm}$ drop of water in field water tube) and farmers practice of continuous standing water which were randomly allotted in three replications. The experimental soil was sandy clay in texture, moderately alkaline in reaction, nonsaline, low in organic carbon content, low in available nitrogen $(\mathrm{N})$, medium in available phosphorous $\left(\mathrm{P}_{2} \mathrm{O}_{5}\right)$ and potassium $\left(\mathrm{K}_{2} \mathrm{O}\right)$. The conventional flooding irrigation practice was followed till 15 DAT for proper establishment. The irrigation water was measured by water meter. After $15 \mathrm{DAT}$, the irrigation schedules were imposed as per the treatment requirements with the help of field water tube. Growth parameters viz., plant height, number of tillers hill ${ }^{-1}$, leaf area index, dry matter production and root volume were measured at periodical intervals. Plant height was recorded at periodical intervals on 30, 60 and 90 days after transplanting and at harvest. The height was measured from the base of the stem to the tip of longest leaf during vegetative stage and up to tip of the panicle of the tallest tiller after panicle emergence and the average of five hills was worked out. The numbers of tillers in five hills were counted at periodical intervals on $30,60 \& 90$ days after transplanting and at harvest and the average was computed as tiller number $\mathrm{m}^{-2}$. Since leaves are the primary photosynthetic organs 
of the plant, it is desirable to express plant growth on leaf area (one side only) basis. Hence, five hills were harvested from the area earmarked for destructive sampling in each net plot for leaf area determination and leaf area was measured by using leaf area meter (Li-COR, Lincoln, Nebraska, USA) and it was expressed as leaf area index (LAI) by dividing the leaf area with ground area occupied by it. The weight of dry matter is an index of productive capacity of the plant. Five hills were harvested from each net plot periodically at 30,60, $90 \mathrm{DAT}$ and at harvest for determining dry matter production. The roots were clipped off from each selected hill, the reminder was cleaned, transferred to properly labelled brown paper bags and then partially dried in the sun. Later on they were subjected to oven drying at $65 \pm 2^{\circ} \mathrm{C}$ until constant weights were recorded and expressed as dry matter production $\left(\mathrm{g} \mathrm{hill}^{-1}\right)$. The plants were removed carefully from the soil without much damage to the roots by using digging fork to disturb the soil. The plants were then cleaned under the tap water to remove the mud and other foreign material. Measurement of the root volume was done by the displacement method using $500 \mathrm{ml}$ measuring cylinder. Initially the container was filled with water until it overflowed from the sprout. Then fresh-washed roots which have been carefully dried with a soft cloth are immersed and the over-flow water volume is measured in a graduated cylinder and the volume of water displaced was taken as root volume expressed in cubic centimetre (cc). The data on various parameters studied during the course of investigation were statistically analyzed as suggested by Gomez and Gomez (1984). Wherever, statistical significance was observed, critical difference (CD) at 0.05 level of probability was worked out for comparison.

\section{Treatment Details}

$\mathrm{I}_{1}$ Continuous submergence of $3 \mathrm{~cm}$ up to PI and thereafter $5 \mathrm{~cm}$ up to PM

$\mathrm{I}_{2} \quad$ AWD - Flooding to a water depth of $3 \mathrm{~cm}$ when water level drops to $5 \mathrm{~cm}$ BGL from 15 DAT to PM

$\mathrm{I}_{3}$ AWD - Flooding to a water depth of $3 \mathrm{~cm}$ when water level drops to $10 \mathrm{~cm}$ BGL from 15 DAT to PM

$\mathrm{I}_{4}$ AWD - Flooding to a water depth of $3 \mathrm{~cm}$ when water level drops to $15 \mathrm{~cm}$ BGL from 15 DAT to PM

$\mathrm{I}_{5}$ AWD - Flooding to a water depth of $5 \mathrm{~cm}$ when water level drops to $5 \mathrm{~cm}$ BGL from 15 DAT to PM

$\mathrm{I}_{6} \quad$ AWD - Flooding to a water depth of $5 \mathrm{~cm}$ when water level drops to $10 \mathrm{~cm}$ BGL from 15 DAT to PM

$\mathrm{I}_{7}$ AWD - Flooding to a water depth of $5 \mathrm{~cm}$ when water level drops to $15 \mathrm{~cm}$ BGL from 15 DAT to PM

$\mathrm{I}_{8} \quad$ AWD - Flooding to a water depth of $3 \mathrm{~cm}$ from 15 DAT to PI and thereafter $5 \mathrm{~cm}$ up to PM when water level drops to $15 \mathrm{~cm}$

\section{Results and Discussion}

\section{Plant height}

Maintenance of Continuous Submergence depth of 3-cm from transplanting to PI and 5- cm from PI to PM $\left(\mathrm{I}_{1}\right)$ had significantly higher plant height over rest of the irrigation regimes except that it was on par with $\mathrm{I}_{2}$ (Flooding to a water depth of 3-cm between 15 DAT to PM as and when ponded water level drops to 5-cm BGL in field water tube), 
$\mathrm{I}_{5}$ (Flooding to a water depth of 5-cm between 15 DAT to PM as and when ponded water level drops to 5-cm BGL in field water tube) and $I_{6}$ (Flooding to a water depth of $5-\mathrm{cm}$ between 15 DAT to PM as and when ponded water level drops to $10-\mathrm{cm}$ BGL in field water tube) at 60,90 DAT and at harvest both in 2013 and 2014. Further, the difference in plant height between $\mathrm{I}_{2}$ (Flooding to a water depth of 3-cm between 15 DAT to PM as and when ponded water level drops to 5-cm BGL in field water tube), $\mathrm{I}_{3}$ (Flooding to a water depth of 3-cm between 15 DAT to PM as and when ponded water level drops to $10-\mathrm{cm}$ BGL in field water tube), $\mathrm{I}_{7}$ (Flooding to a water depth of 5-cm between 15 DAT to PM as and when ponded water level drops to $15-\mathrm{cm}$ BGL in field water tube) and $\mathrm{I}_{8}$ (Flooding to a water depth of 3-cm from 15

DAT to PI and 5-cm from PI to PM as and when ponded water level drops to $15-\mathrm{cm}$ BGL in field water tube) was not significant. Whereas, lowest plant height was registered $\mathrm{I}_{4}$ (Flooding to a water depth of 3-cm between 15 DAT to PM as and when ponded water level drops to $15-\mathrm{cm}$ BGL in field water tube) at all the growth stages in both the years (Table 1).

Plant height plays an important role in the capture of solar radiation. Several researchers reported production of taller rice plants due to maintenance of optimal irrigation regime (Chowdhury et al., 2014). Water stress imposed at any growth stage of rice before anthesis significantly reduced the plant height (Sariam and Anuar, 2010). Further the availability of sufficient amount of moisture optimizes the metabolic process in plant cells and increases the effectiveness of the mineral nutrients. These results are in agreement with the findings of Sandhu et al., (2012) and Kumar et al., (2013). On the other hand the practice of AWD irrigation regime of reflooding to $3 \mathrm{~cm}$ depth of water whenever the water level dropped to $15 \mathrm{~cm}$ depth in the field water tube caused reduction in plant height owing to water stress (Kobata and Takami, 1983; Packiaraj and Venkatraman, 1991).

\section{Number of tillers hill-1}

At $60 \& 90$ DAT and at harvest significantly higher number of tillers hill $^{-1}$ of rice were produced by the crop in Continuous Submergence depth of 3-cm from transplanting to PI and $5 \mathrm{~cm}$ from PI to PM $\left(\mathrm{I}_{1}\right)$ over AWD irrigation regimes of $\mathrm{I}_{3}$ (Flooding to a water depth of 3-cm between 15 DAT to PM as and when ponded water level drops to $10-\mathrm{cm}$ BGL in field water tube), $\mathrm{I}_{4}$ (Flooding to a water depth of $3-\mathrm{cm}$ between 15 DAT to PM as and when ponded water level drops to $15-\mathrm{cm}$ BGL in field water tube), $\mathrm{I}_{7}$ (Flooding to a water depth of $5-\mathrm{cm}$ between 15 DAT to PM as and when ponded water level drops to $15-\mathrm{cm}$ BGL in field water tube) and $\mathrm{I}_{8}$ (Flooding to a water depth of 3$\mathrm{cm}$ from 15 DAT to PI and 5-cm from PI to $\mathrm{PM}$ as and when ponded water level drops to $15-\mathrm{cm}$ BGL in field water tube) during both the years of 2013 and 2014. However, the crop in AWD irrigation regimes of $\mathrm{I}_{2}$ (Flooding to a water depth of 3-cm between 15 DAT to PM as and when ponded water level drops to 5-cm BGL in field water tube), $\mathrm{I}_{5}$ (Flooding to a water depth of $5-\mathrm{cm}$ between 15 DAT to PM as and when ponded water level drops to 5-cm BGL in field water tube) and $\mathrm{I}_{6}$ (Flooding to a water depth of $5-\mathrm{cm}$ between 15 DAT to PM as and when ponded water level drops to $10-\mathrm{cm}$ BGL in field water tube) performed statistically on par with $\mathrm{I}_{1}$. Significantly lowest no. of tillers hill $^{-1}$ were registered by the crop in $\mathrm{I}_{8}$ (Flooding to a water depth of 3-cm from 15 DAT to PI and $5-\mathrm{cm}$ from PI to PM as and when ponded water level drops to $15-\mathrm{cm}$ BGL in field water tube) during both the years of study (Table 2). 
Tillering in rice is very sensitive to water stress, being almost halved if conditions are dry enough (Peterson et al., 1984). Therefore higher number of tillers hill ${ }^{-1}$ in $\mathrm{I}_{1}$ and AWD irrigation regimes of $I_{2}, I_{5}$ and $I_{6}$ could be traced to optimal irrigation regime in these treatments contributing to higher soil moisture content in the root zone, better plant water balance (RWC and LWP), LAI, LAD and CGR. These results are in agreement with Pandey et al., (2010) and Kumar et al., (2013). On the other hand the fewer tillers in $\mathrm{I}_{4}, \mathrm{I}_{7}$ and $\mathrm{I}_{8}$ could be traced to plant water stress (RWC and LWP,) owing to soil water deficit resulting in reduction of plant height and LAI, and in turn the amount of photosynthetically active radiation. This is expected since leaf elongation in rice is the first and most sensitive process altered by water deficits, and consequently, so is leaf appearance too. This in turn, decreases the number of potential sites for tillering. This is because during tillering, plant produces leaves and due to reduced growth as a result of water stress, the leaf initiation gets decreased, and thus tends to reduce tillering.

The dependence of tiller production on plant height and LAI was evident from significant $(\mathrm{P}=0.01)$ and positive correlation between these traits (Figure 1 and 2). Determination coefficient $\left(\mathrm{R}^{2}\right)$ calculated for the relationship between tillers hill ${ }^{-1}$ versus plant height and LAI was $\mathrm{R}^{2}=0.933$ and $\mathrm{R}^{2}=0.740$, respectively, which showed a linear increase in tiller hill ${ }^{-1}$ with the corresponding increase in plant height and LAI.

\section{Leaf Area Index (LAI)}

At 60 and 90 DAT, and at harvest, LAI registered under $\mathrm{I}_{1}$ (Continuous Submergence depth of $3-\mathrm{cm}$ from transplanting to PI and 5 $\mathrm{cm}$ from PI to PM) was significantly superior over AWD irrigation regimes of $\mathrm{I}_{3}$ (Flooding to a water depth of $3-\mathrm{cm}$ between 15 DAT to
$\mathrm{PM}$ as and when ponded water level drops to $10-\mathrm{cm}$ BGL in field water tube), $\mathrm{I}_{4}$ (Flooding to a water depth of $3-\mathrm{cm}$ between 15 DAT to $\mathrm{PM}$ as and when ponded water level drops to $15-\mathrm{cm}$ BGL in field water tube), $\mathrm{I}_{7}$ (Flooding to a water depth of 5-cm between 15 DAT to $\mathrm{PM}$ as and when ponded water level drops to $15-\mathrm{cm}$ BGL in field water tube) and $\mathrm{I}_{8}$ (Flooding to a water depth of 3-cm from 15 DAT to PI and 5-cm from PI to PM as and when ponded water level drops to $15-\mathrm{cm}$ BGL in field water tube) but statistically on par with $\mathrm{I}_{2}$ (Flooding to a water depth of $3-\mathrm{cm}$ between 15 DAT to PM as and when ponded water level drops to 5-cm BGL in field water tube), $\mathrm{I}_{5}$ (Flooding to a water depth of $5-\mathrm{cm}$ between 15 DAT to PM as and when ponded water level drops to 5-cm BGL in field water tube) and $\mathrm{I}_{6}$ (Flooding to a water depth of 5$\mathrm{cm}$ between 15 DAT to PM as and when ponded water level drops to 10-cm BGL in field water tube). Further, the difference in LAI between AWD irrigation regimes $\mathrm{I}_{3}, \mathrm{I}_{7}$ and $\mathrm{I}_{8}$ and that between $\mathrm{I}_{2}, \mathrm{I}_{3}$ and $\mathrm{I}_{7}$ was not significant. Lowest LAI was produced by the crop in $\mathrm{I}_{8}$ treatment (Table 3).

LAI is an important indicator of total photosynthetic surface area available to the plant for the production of photosynthates which accumulate in the developing sink. The variation in LAI is an important biophysical parameter that eventually determines crop productivity because it influences the light interception and transpiration by the crop canopy (Fageria et al., 2006). LAI is the efficiency of photosynthetic process and on the extent of photosynthetic surface (Lockhart and Wiseman, 1988). The optimal leaf area index for photosynthesis in rice is $>4.0$ (Murata, 1967). Wopereis et al., (1996) extensively investigated the effect of nonsubmerged periods in lowland rice on crop growth and yield formation. They found that leaf expansion stopped when soil water potentials ranged from -50 to $-250 \mathrm{kPa}$, 
depending on crop age and season. Leaf transpiration rates declined when potentials dropped below $-100 \mathrm{kPa}$. Other growthreducing processes such as leaf rolling and accelerated leaf death occurred only at potentials below $-200 \mathrm{kPa}$. Likewise $\mathrm{Lu}$ et al., (2000) and Belder et al., (2004) reported LAI to be significantly decreased when soil water potential was allowed to drop to -10 $\mathrm{kPa}$ in intermittent irrigation. Determination coefficient $\left(\mathrm{R}^{2}\right)$ calculated for the relationship between LAI versus tiller hill ${ }^{-1}$ was $\mathrm{R}^{2}=$ 0.740, (Figure 3) which showed a linear increase in LAI with the corresponding increase in tiller hill ${ }^{-1}$.

\section{Root volume $\left(\mathrm{cm}^{3}\right)$}

The root volume did not differ significantly among irrigation regimes at 30 DAT during both the years (Table 4). However at 60 and 90 DAT, and at harvest in 2013 and 2014 years significantly higher root volume was observed in AWD irrigation regimes of $\mathrm{I}_{5}$ (Flooding to a water depth of 5-cm between 15 DAT to PM as and when ponded water level drops to 5-cm BGL in field water tube) and $\mathrm{I}_{6}$ (Flooding to a water depth of $5-\mathrm{cm}$ between 15 DAT to PM as and when ponded water level drops to $10-\mathrm{cm}$ BGL in field water tube) over other water regimes viz., $\mathrm{I}_{1}$ (Continuous Submergence depth of $3-\mathrm{cm}$ from transplanting to PI and $5 \mathrm{~cm}$ from PI to $\mathrm{PM}$ ), $\mathrm{I}_{2}$ (Flooding to a water depth of $3-\mathrm{cm}$ between 15 DAT to PM as and when ponded water level drops to 5-cm BGL in field water tube), $\mathrm{I}_{3}$ (Flooding to a water depth of $3-\mathrm{cm}$ between 15 DAT to PM as and when ponded water level drops to $10-\mathrm{cm}$ BGL in field water tube), $\mathrm{I}_{4}$ (Flooding to a water depth of $3-\mathrm{cm}$ between 15 DAT to PM as and when ponded water level drops to $15-\mathrm{cm}$ BGL in field water tube), $\mathrm{I}_{7}$ (Flooding to a water depth of $5-\mathrm{cm}$ between 15 DAT to PM as and when ponded water level drops to $15-\mathrm{cm}$ BGL in field water tube) and $\mathrm{I}_{8}$ (Flooding to a water depth of 3- cm from 15 DAT to PI and 5-cm from PI to $\mathrm{PM}$ as and when ponded water level drops to $15-\mathrm{cm}$ BGL in field water tube) in both the years, 2013 and 2014. This could be attributed to increased root oxidation activity and root source cytokinins (Thakur et al., 2011 and Dandeniya and Thies, 2012). Under progressive soil drying, root responses include increased root length density (Siopongco et al., 2005) as a result of plastic lateral root development (Kamoshita et al., 2000). Bumrungbood et al., (2015) in their field studies also found higher root mass of rice under AWD water regimes (10,353 to $11,353 \mathrm{~km} \mathrm{ha}^{-1}$ ) as compared to continuous submergence $\left(8,848 \mathrm{~km} \mathrm{ha}^{-1}\right)$.

The importance of maintaining adequate LAI for development effective root system for rice raised under AWD irrigation regimes was evident from significant and positive association between these traits. The explained variation in root volume by LAI as indicated by a calculated Determination Coefficient was $\mathrm{R}^{2}=0.683$ (Figure 4 ).

\section{Dry matter production}

Significantly higher dry matter was produced in Continuous Submergence depth of 3-cm from transplanting to PI and $5 \mathrm{~cm}$ from PI to PM ( $\left.\mathrm{I}_{1}\right)$ treatment over AWD irrigation regimes of $\mathrm{I}_{3}$ (Flooding to a water depth of 3$\mathrm{cm}$ between 15 DAT to PM as and when ponded water level drops to $10-\mathrm{cm}$ BGL in field water tube), $\mathrm{I}_{4}$ (Flooding to a water depth of 3-cm between 15 DAT to PM as and when ponded water level drops to $15-\mathrm{cm}$ BGL in field water tube), $\mathrm{I}_{7}$ (Flooding to a water depth of 5-cm between 15 DAT to PM as and when ponded water level drops to $15-\mathrm{cm}$ BGL in field water tube) and $\mathrm{I}_{8}$ (Flooding to a water depth of 3-cm from 15 DAT to PI and $5-\mathrm{cm}$ from PI to PM as and when ponded water level drops to $15-\mathrm{cm}$ BGL in field water tube). 
Table.1 Plant height $(\mathrm{cm})$ of rice as influenced by different AWD irrigation regimes during kharif, 2013 and 2014

\begin{tabular}{|c|c|c|c|c|c|c|c|c|c|}
\hline \multirow{2}{*}{ Code } & \multirow{2}{*}{ Description of Treatment } & \multicolumn{2}{|c|}{30 DAT } & \multicolumn{2}{|c|}{$60 \mathrm{DAT}$} & \multicolumn{2}{|c|}{90 DAT } & \multicolumn{2}{|c|}{ At Harvest } \\
\hline & & 2013 & 2014 & 2013 & 2014 & 2013 & 2014 & 2013 & 2014 \\
\hline $\mathbf{I}_{\mathbf{1}}$ & $\begin{array}{l}\text { Continuous submergence of } 3 \mathrm{~cm} \text { up to PI and thereafter } 5 \mathrm{~cm} \text { up } \\
\text { to PM }\end{array}$ & 61.5 & 66.6 & 99.9 & 101.6 & 103.5 & 105.3 & 106.8 & 107.8 \\
\hline $\mathbf{I}_{2}$ & $\begin{array}{l}\text { AWD - Flooding to a water depth of } 3 \mathrm{~cm} \text { when water level } \\
\text { drops to } 5 \mathrm{~cm} \text { BGL from } 15 \text { DAT to PM }\end{array}$ & 58.6 & 63.2 & 90.9 & 94.8 & 95.9 & 97.6 & 96.8 & 98.3 \\
\hline $\mathbf{I}_{3}$ & $\begin{array}{l}\text { AWD - Flooding to a water depth of } 3 \mathrm{~cm} \text { when water level } \\
\text { drops to } 10 \mathrm{~cm} \text { BGL from } 15 \text { DAT to PM }\end{array}$ & 56.0 & 59.5 & 86.3 & 90.4 & 90.8 & 93.1 & 92.8 & 96.3 \\
\hline $\mathbf{I}_{4}$ & $\begin{array}{l}\text { AWD - Flooding to a water depth of } 3 \mathrm{~cm} \text { when water level } \\
\text { drops to } 15 \mathrm{~cm} \text { BGL from } 15 \text { DAT to PM }\end{array}$ & 50.8 & 55.8 & 75.5 & 77.2 & 77.4 & 79.8 & 82.1 & 86.2 \\
\hline $\mathbf{I}_{5}$ & $\begin{array}{l}\text { AWD - Flooding to a water depth of } 5 \mathrm{~cm} \text { when water level } \\
\text { drops to } 5 \mathrm{~cm} \text { BGL from } 15 \text { DAT to PM }\end{array}$ & 60.0 & 64.2 & 97.7 & 99.6 & 102.3 & 102.9 & 103.0 & 106.0 \\
\hline $\mathbf{I}_{6}$ & $\begin{array}{l}\text { AWD - Flooding to a water depth of } 5 \mathrm{~cm} \text { when water level } \\
\text { drops to } 10 \mathrm{~cm} \text { BGL from } 15 \text { DAT to PM }\end{array}$ & 59.8 & 63.3 & 93.7 & 96.3 & 100.0 & 100.8 & 101.2 & 102.6 \\
\hline $\mathbf{I}_{7}$ & $\begin{array}{l}\text { AWD - Flooding to a water depth of } 5 \mathrm{~cm} \text { when water level } \\
\text { drops to } 15 \mathrm{~cm} \text { BGL from } 15 \text { DAT to PM }\end{array}$ & 56.4 & 61.5 & 85.8 & 88.0 & 90.0 & 90.2 & 90.9 & 94.7 \\
\hline $\mathbf{I}_{8}$ & $\begin{array}{l}\text { AWD - Flooding to a water depth of } 3 \mathrm{~cm} \text { from } 15 \text { DAT to PI } \\
\text { and thereafter } 5 \mathrm{~cm} \text { up to PM when water level drops to } 15 \mathrm{~cm}\end{array}$ & 54.3 & 57.5 & 82.1 & 82.8 & 85.6 & 87.4 & 90.6 & 93.3 \\
\hline \multicolumn{2}{|c|}{ SEm \pm} & 2.3 & 2.3 & 2.9 & 2.9 & 4.0 & 3.9 & 4.5 & 3.2 \\
\hline \multicolumn{2}{|c|}{$\mathrm{CD}$ at $\mathrm{P}=5 \%$} & NS & NS & 8.9 & 8.7 & 12.2 & 11.7 & 13.6 & 9.7 \\
\hline \multicolumn{2}{|c|}{ General Mean } & 57.1 & 61.4 & 88.9 & 91.3 & 93.1 & 94.6 & 95.5 & 98.1 \\
\hline
\end{tabular}


Table.2 Number of tillers hill-1 of rice as influenced by different AWD irrigation regimes during kharif, 2013 and 2014

\begin{tabular}{|c|c|c|c|c|c|c|c|c|c|}
\hline \multirow{2}{*}{ Code } & \multirow{2}{*}{ Description of Treatment } & \multicolumn{2}{|c|}{30 DAT } & \multicolumn{2}{|c|}{60 DAT } & \multicolumn{2}{|c|}{90 DAT } & \multicolumn{2}{|c|}{ At Harvest } \\
\hline & & 2013 & 2014 & 2013 & 2014 & 2013 & 2014 & 2013 & 2014 \\
\hline $\mathbf{I}_{1}$ & $\begin{array}{l}\text { Continuous submergence of } 3 \mathrm{~cm} \text { up to PI and thereafter } 5 \mathrm{~cm} \text { up to } \\
\mathrm{PM}\end{array}$ & 14.6 & 16.9 & 22.2 & 24.5 & 21.0 & 21.0 & 17.9 & 19.5 \\
\hline $\mathbf{I}_{2}$ & $\begin{array}{l}\text { AWD - Flooding to a water depth of } 3 \mathrm{~cm} \text { when water level drops to } \\
5 \mathrm{~cm} \text { BGL from } 15 \text { DAT to PM }\end{array}$ & 12.0 & 13.7 & 18.2 & 20.4 & 14.6 & 17.0 & 14.9 & 15.6 \\
\hline $\mathbf{I}_{3}$ & $\begin{array}{l}\text { AWD - Flooding to a water depth of } 3 \mathrm{~cm} \text { when water level drops to } \\
10 \mathrm{~cm} \text { BGL from } 15 \text { DAT to PM }\end{array}$ & 12.1 & 12.2 & 16.1 & 19.6 & 14.0 & 16.3 & 14.0 & 14.5 \\
\hline $\mathbf{I}_{4}$ & $\begin{array}{l}\text { AWD - Flooding to a water depth of } 3 \mathrm{~cm} \text { when water level drops to } \\
15 \mathrm{~cm} \text { BGL from } 15 \text { DAT to PM }\end{array}$ & 11.5 & 11.1 & 13.5 & 15.1 & 11.3 & 13.3 & 10.9 & 12.2 \\
\hline $\mathbf{I}_{5}$ & $\begin{array}{l}\text { AWD - Flooding to a water depth of } 5 \mathrm{~cm} \text { when water level drops to } \\
5 \mathrm{~cm} \text { BGL from } 15 \text { DAT to PM }\end{array}$ & 13.3 & 14.7 & 21.0 & 23.1 & 19.3 & 20.0 & 16.4 & 18.5 \\
\hline $\mathbf{I}_{6}$ & $\begin{array}{l}\text { AWD - Flooding to a water depth of } 5 \mathrm{~cm} \text { when water level drops to } \\
10 \mathrm{~cm} \text { BGL from } 15 \text { DAT to PM }\end{array}$ & 12.8 & 14.1 & 19.9 & 22.2 & 16.6 & 18.6 & 15.5 & 17.7 \\
\hline $\mathbf{I}_{7}$ & $\begin{array}{l}\text { AWD - Flooding to a water depth of } 5 \mathrm{~cm} \text { when water level drops to } \\
15 \mathrm{~cm} \text { BGL from } 15 \text { DAT to PM }\end{array}$ & 12.8 & 12.0 & 15.4 & 19.8 & 13.3 & 14.6 & 12.4 & 13.6 \\
\hline $\mathbf{I}_{8}$ & $\begin{array}{l}\text { AWD - Flooding to a water depth of } 3 \mathrm{~cm} \text { from } 15 \text { DAT to PI and } \\
\text { thereafter } 5 \mathrm{~cm} \text { up to PM when water level drops to } 15 \mathrm{~cm}\end{array}$ & 11.6 & 11.8 & 14.4 & 16.0 & 12.6 & 13.4 & 12.3 & 12.9 \\
\hline \multicolumn{2}{|c|}{ SEm \pm} & 0.7 & 1.2 & 1.8 & 1.0 & 1.7 & 1.5 & 1.0 & 1.2 \\
\hline \multicolumn{2}{|c|}{$\mathrm{CD}$ at $\mathrm{P}=5 \%$} & NS & NS & 5.5 & 3.2 & 5.1 & 4.6 & 3.2 & 4.6 \\
\hline \multicolumn{2}{|c|}{ General Mean } & 12.5 & 13.3 & $\mathbf{1 7 . 5}$ & 20.0 & 15.3 & 16.7 & 14.4 & 15.5 \\
\hline
\end{tabular}


Table.3 Leaf area index of rice as influenced by different AWD irrigation resumes during kharif, 2013 and 2014

\begin{tabular}{|c|c|c|c|c|c|c|c|c|c|}
\hline \multirow{2}{*}{ Code } & \multirow{2}{*}{ Description of Treatment } & \multicolumn{2}{|c|}{30 DAT } & \multicolumn{2}{|c|}{$60 \mathrm{DAT}$} & \multicolumn{2}{|c|}{90 DAT } & \multicolumn{2}{|c|}{ At Harvest } \\
\hline & & 2013 & 2014 & 2013 & 2014 & 2013 & 2014 & 2013 & 2014 \\
\hline $\mathbf{I}_{1}$ & $\begin{array}{l}\text { Continuous submergence of } 3 \mathrm{~cm} \text { up to PI and thereafter } 5 \mathrm{~cm} \text { up to } \\
\mathrm{PM}\end{array}$ & 1.88 & 1.89 & 5.47 & 5.51 & 4.15 & 4.16 & 1.03 & 1.05 \\
\hline $\mathbf{I}_{2}$ & $\begin{array}{l}\text { AWD - Flooding to a water depth of } 3 \mathrm{~cm} \text { when water level drops to } \\
5 \mathrm{~cm} \text { BGL from } 15 \text { DAT to PM }\end{array}$ & 1.82 & 1.84 & 5.20 & 5.27 & 3.98 & 4.01 & 0.98 & 1.00 \\
\hline $\mathbf{I}_{3}$ & $\begin{array}{l}\text { AWD - Flooding to a water depth of } 3 \mathrm{~cm} \text { when water level drops to } \\
10 \mathrm{~cm} \text { BGL from } 15 \text { DAT to PM }\end{array}$ & 1.65 & 1.76 & 4.90 & 4.92 & 3.63 & 3.77 & 0.83 & 0.86 \\
\hline $\mathbf{I}_{4}$ & $\begin{array}{l}\text { AWD - Flooding to a water depth of } 3 \mathrm{~cm} \text { when water level drops to } \\
15 \mathrm{~cm} \text { BGL from } 15 \text { DAT to PM }\end{array}$ & 1.55 & 1.59 & 3.70 & 3.85 & 2.65 & 2.86 & 0.65 & 0.66 \\
\hline $\mathbf{I}_{5}$ & $\begin{array}{l}\text { AWD - Flooding to a water depth of } 5 \mathrm{~cm} \text { when water level drops to } \\
5 \mathrm{~cm} \text { BGL from } 15 \text { DAT to PM }\end{array}$ & 1.87 & 1.87 & 5.32 & 5.46 & 4.09 & 4.12 & 1.01 & 1.03 \\
\hline $\mathbf{I}_{6}$ & $\begin{array}{l}\text { AWD - Flooding to a water depth of } 5 \mathrm{~cm} \text { when water level drops to } \\
10 \mathrm{~cm} \text { BGL from } 15 \text { DAT to PM }\end{array}$ & 1.85 & 1.82 & 5.27 & 5.37 & 4.06 & 4.08 & 0.87 & 0.89 \\
\hline $\mathbf{I}_{7}$ & $\begin{array}{l}\text { AWD - Flooding to a water depth of } 5 \mathrm{~cm} \text { when water level drops to } \\
15 \mathrm{~cm} \text { BGL from } 15 \text { DAT to PM }\end{array}$ & 1.79 & 1.80 & 4.75 & 4.81 & 3.58 & 3.72 & 0.79 & 0.80 \\
\hline $\mathbf{I}_{8}$ & $\begin{array}{l}\text { AWD - Flooding to a water depth of } 3 \mathrm{~cm} \text { from } 15 \text { DAT to PI and } \\
\text { thereafter } 5 \mathrm{~cm} \text { up to PM when water level drops to } 15 \mathrm{~cm}\end{array}$ & 1.64 & 1.78 & 4.41 & 4.62 & 3.25 & 3.59 & 0.72 & 0.73 \\
\hline \multicolumn{2}{|c|}{ SEm \pm} & 0.15 & 0.06 & 0.18 & 0.19 & 0.16 & 0.13 & 0.04 & 0.03 \\
\hline \multicolumn{2}{|c|}{$\mathrm{CD}$ at $\mathrm{P}=5 \%$} & NS & NS & \begin{tabular}{|l|}
0.54 \\
\end{tabular} & $\mathbf{0 . 5 7}$ & 0.49 & 0.38 & 0.11 & 0.09 \\
\hline \multicolumn{2}{|c|}{ General Mean } & 1.75 & 1.79 & 4.87 & 4.97 & 3.67 & 3.78 & 0.86 & 0.87 \\
\hline
\end{tabular}


Table.4 Root volume (cc) of rice as influenced by different AWD irrigation regimes during kharif 2013 and 2014

\begin{tabular}{|c|c|c|c|c|c|c|c|c|c|}
\hline \multirow{2}{*}{ Code } & \multirow{2}{*}{ Description of Treatment } & \multicolumn{2}{|c|}{30 DAT } & \multicolumn{2}{|c|}{60 DAT } & \multicolumn{2}{|c|}{90 DAT } & \multicolumn{2}{|c|}{ At Harvest } \\
\hline & & 2013 & 2014 & 2013 & 2014 & 2013 & 2014 & 2013 & 2014 \\
\hline $\mathbf{I}_{\mathbf{1}}$ & $\begin{array}{l}\text { Continuous submergence of } 3 \mathrm{~cm} \text { up to PI and thereafter } 5 \mathrm{~cm} \\
\text { up to PM }\end{array}$ & 27.57 & 28.13 & 30.20 & 36.73 & 35.67 & 37.10 & 34.49 & 36.37 \\
\hline $\mathbf{I}_{2}$ & $\begin{array}{l}\text { AWD - Flooding to a water depth of } 3 \mathrm{~cm} \text { when water level } \\
\text { drops to } 5 \mathrm{~cm} \text { BGL from } 15 \text { DAT to PM }\end{array}$ & 20.69 & 24.26 & 40.50 & 42.70 & 40.23 & 40.83 & 38.61 & 39.30 \\
\hline $\mathbf{I}_{3}$ & $\begin{array}{l}\text { AWD - Flooding to a water depth of } 3 \mathrm{~cm} \text { when water level } \\
\text { drops to } 10 \mathrm{~cm} \text { BGL from } 15 \text { DAT to PM }\end{array}$ & 19.48 & 22.72 & 37.34 & 39.23 & 38.90 & 39.43 & 36.10 & 37.93 \\
\hline $\mathbf{I}_{4}$ & $\begin{array}{l}\text { AWD - Flooding to a water depth of } 3 \mathrm{~cm} \text { when water level } \\
\text { drops to } 15 \mathrm{~cm} \text { BGL from } 15 \text { DAT to PM }\end{array}$ & 22.91 & 24.99 & 30.30 & 36.03 & 34.49 & 37.37 & 34.57 & 35.43 \\
\hline $\mathbf{I}_{5}$ & $\begin{array}{l}\text { AWD - Flooding to a water depth of } 5 \mathrm{~cm} \text { when water level } \\
\text { drops to } 5 \mathrm{~cm} \text { BGL from } 15 \text { DAT to PM }\end{array}$ & 19.89 & 23.13 & 51.47 & 52.56 & 55.45 & 56.10 & 52.23 & 53.90 \\
\hline $\mathbf{I}_{6}$ & $\begin{array}{l}\text { AWD - Flooding to a water depth of } 5 \mathrm{~cm} \text { when water level } \\
\text { drops to } 10 \mathrm{~cm} \text { BGL from } 15 \text { DAT to PM }\end{array}$ & 22.47 & 23.47 & 48.00 & 49.20 & 50.43 & 51.13 & 47.20 & 50.53 \\
\hline $\mathbf{I}_{7}$ & $\begin{array}{l}\text { AWD - Flooding to a water depth of } 5 \mathrm{~cm} \text { when water level } \\
\text { drops to } 15 \mathrm{~cm} \text { BGL from } 15 \text { DAT to PM }\end{array}$ & 23.53 & 25.38 & 45.33 & 46.04 & 47.71 & 48.13 & 45.71 & 47.70 \\
\hline $\mathbf{I}_{8}$ & $\begin{array}{l}\text { AWD - Flooding to a water depth of } 3 \mathrm{~cm} \text { from } 15 \text { DAT to PI } \\
\text { and thereafter } 5 \mathrm{~cm} \text { up to PM when water level drops to } 15 \mathrm{~cm}\end{array}$ & 26.80 & 27.10 & 36.00 & 37.67 & 43.37 & 43.43 & 40.57 & 42.13 \\
\hline \multicolumn{2}{|c|}{ SEm \pm} & 1.93 & 1.38 & 1.51 & 1.54 & 2.41 & 1.56 & 2.29 & 1.39 \\
\hline \multicolumn{2}{|c|}{$C D$ at $P=5 \%$} & NS & NS & 4.59 & 4.66 & 7.30 & 4.74 & 6.94 & 4.21 \\
\hline \multicolumn{2}{|c|}{ General Mean } & 22.91 & 24.89 & 39.89 & 42.52 & 43.28 & 44.19 & 41.18 & 42.91 \\
\hline
\end{tabular}


Table.5 Dry matter production (g hill-1) of rice as influenced by different AWD irrigation regimes during kharif, 2013 and 2014

\begin{tabular}{|c|c|c|c|c|c|c|c|c|c|}
\hline \multirow{2}{*}{ Code } & \multirow{2}{*}{ Description of Treatment } & \multicolumn{2}{|c|}{30 DAT } & \multicolumn{2}{|c|}{60 DAT } & \multicolumn{2}{|c|}{90 DAT } & \multicolumn{2}{|c|}{ At Harvest } \\
\hline & & 2013 & 2014 & 2013 & 2014 & 2013 & 2014 & 2013 & 2014 \\
\hline $\mathbf{I}_{1}$ & $\begin{array}{l}\text { Continuous submergence of } 3 \mathrm{~cm} \text { up to PI and thereafter } 5 \mathrm{~cm} \\
\text { up to PM }\end{array}$ & 21.21 & 23.06 & 33.90 & 35.83 & 44.95 & 47.27 & 54.04 & 56.37 \\
\hline $\mathbf{I}_{2}$ & $\begin{array}{l}\text { AWD - Flooding to a water depth of } 3 \mathrm{~cm} \text { when water level } \\
\text { drops to } 5 \mathrm{~cm} \text { BGL from } 15 \text { DAT to PM }\end{array}$ & 17.38 & 19.17 & 29.36 & 32.50 & 38.20 & 43.03 & 46.83 & 50.80 \\
\hline $\mathbf{I}_{3}$ & $\begin{array}{l}\text { AWD - Flooding to a water depth of } 3 \mathrm{~cm} \text { when water level } \\
\text { drops to } 10 \mathrm{~cm} \text { BGL from } 15 \text { DAT to PM }\end{array}$ & 16.28 & 18.06 & 28.50 & 30.20 & 37.46 & 41.50 & 46.51 & 48.46 \\
\hline $\mathbf{I}_{4}$ & $\begin{array}{l}\text { AWD - Flooding to a water depth of } 3 \mathrm{~cm} \text { when water level } \\
\text { drops to } 15 \mathrm{~cm} \text { BGL from } 15 \text { DAT to PM }\end{array}$ & 15.08 & 16.09 & 20.46 & 23.62 & 23.46 & 28.50 & 27.9 & 31.46 \\
\hline $\mathbf{I}_{5}$ & $\begin{array}{l}\text { AWD - Flooding to a water depth of } 5 \mathrm{~cm} \text { when water level } \\
\text { drops to } 5 \mathrm{~cm} \text { BGL from } 15 \text { DAT to PM }\end{array}$ & 19.43 & 21.66 & 32.43 & 34.25 & 42.57 & 46.13 & 52.64 & 53.10 \\
\hline $\mathbf{I}_{6}$ & $\begin{array}{l}\text { AWD - Flooding to a water depth of } 5 \mathrm{~cm} \text { when water level } \\
\text { drops to } 10 \mathrm{~cm} \text { BGL from } 15 \text { DAT to PM }\end{array}$ & 18.95 & 21.72 & 30.88 & 34.25 & 40.95 & 44.23 & 48.87 & 51.54 \\
\hline $\mathbf{I}_{7}$ & $\begin{array}{l}\text { AWD - Flooding to a water depth of } 5 \mathrm{~cm} \text { when water level } \\
\text { drops to } 15 \mathrm{~cm} \text { BGL from } 15 \text { DAT to PM }\end{array}$ & 16.46 & 19.50 & 28.06 & 30.33 & 38.60 & 40.46 & 45.78 & 46.25 \\
\hline $\mathbf{I}_{8}$ & $\begin{array}{l}\text { AWD - Flooding to a water depth of } 3 \mathrm{~cm} \text { from } 15 \text { DAT to PI } \\
\text { and thereafter } 5 \mathrm{~cm} \text { up to PM when water level drops to } 15 \mathrm{~cm}\end{array}$ & 17.98 & 16.94 & 21.57 & 24.61 & 28.50 & 30.83 & 33.13 & 35.06 \\
\hline \multicolumn{2}{|c|}{ SEm \pm} & 2.36 & 2.44 & 1.44 & 1.46 & 1.53 & 1.34 & 2.04 & 2.00 \\
\hline \multicolumn{2}{|c|}{$\mathrm{CD}$ at $\mathrm{P}=5 \%$} & NS & NS & 4.38 & 4.42 & 4.63 & 4.06 & 6.19 & 6.06 \\
\hline \multicolumn{2}{|c|}{ General Mean } & 17.84 & 19.52 & 28.14 & \begin{tabular}{|l|}
30.69 \\
\end{tabular} & \begin{tabular}{|l|}
36.83 \\
\end{tabular} & 40.24 & 44.46 & 46.63 \\
\hline
\end{tabular}


Fig.1 Regression of rice tillers hill-1 on plant height

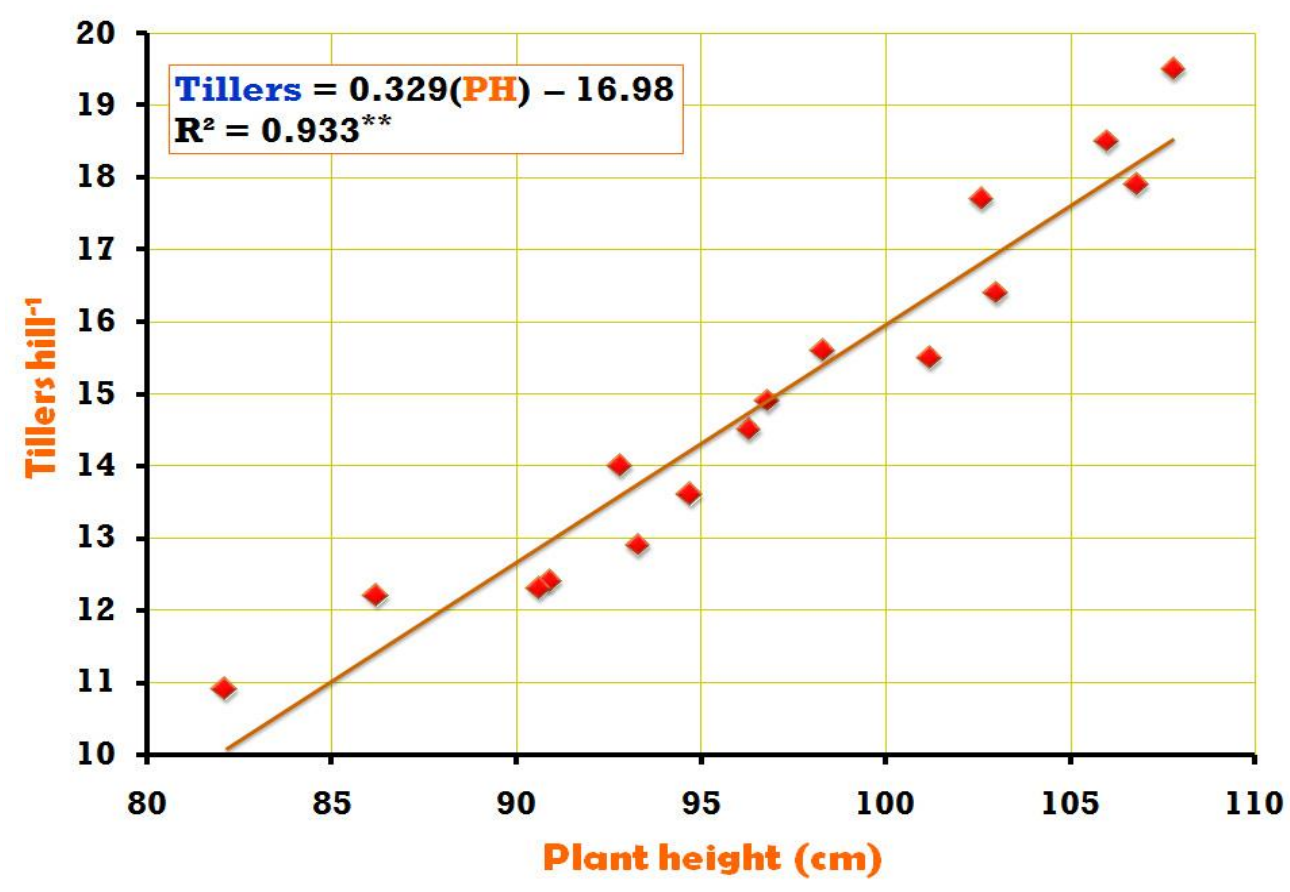

Fig.2 Regression of rice tillers hill-1 on LAI

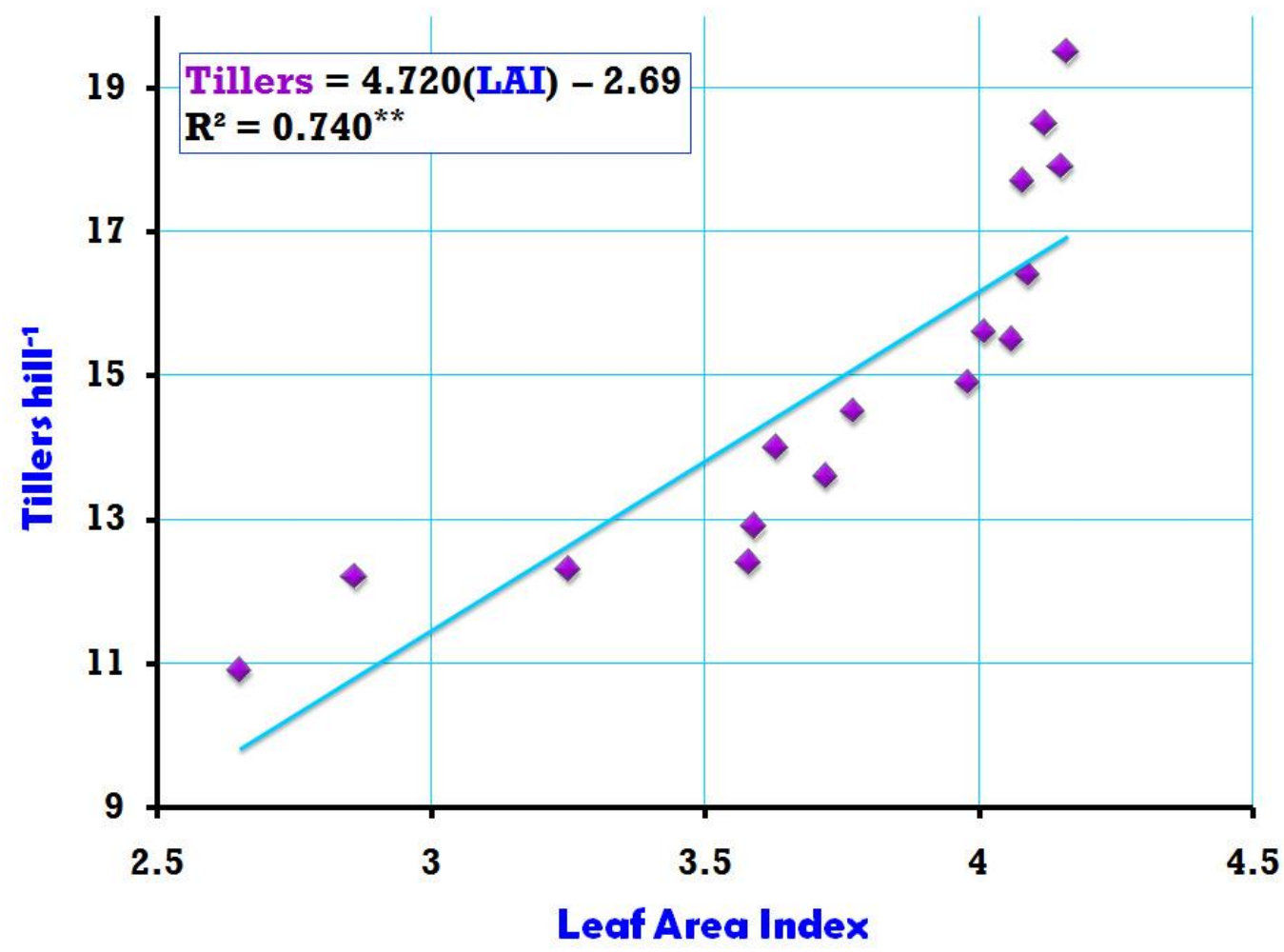


Fig.3 Regression of rice LAI on tillers hill-1

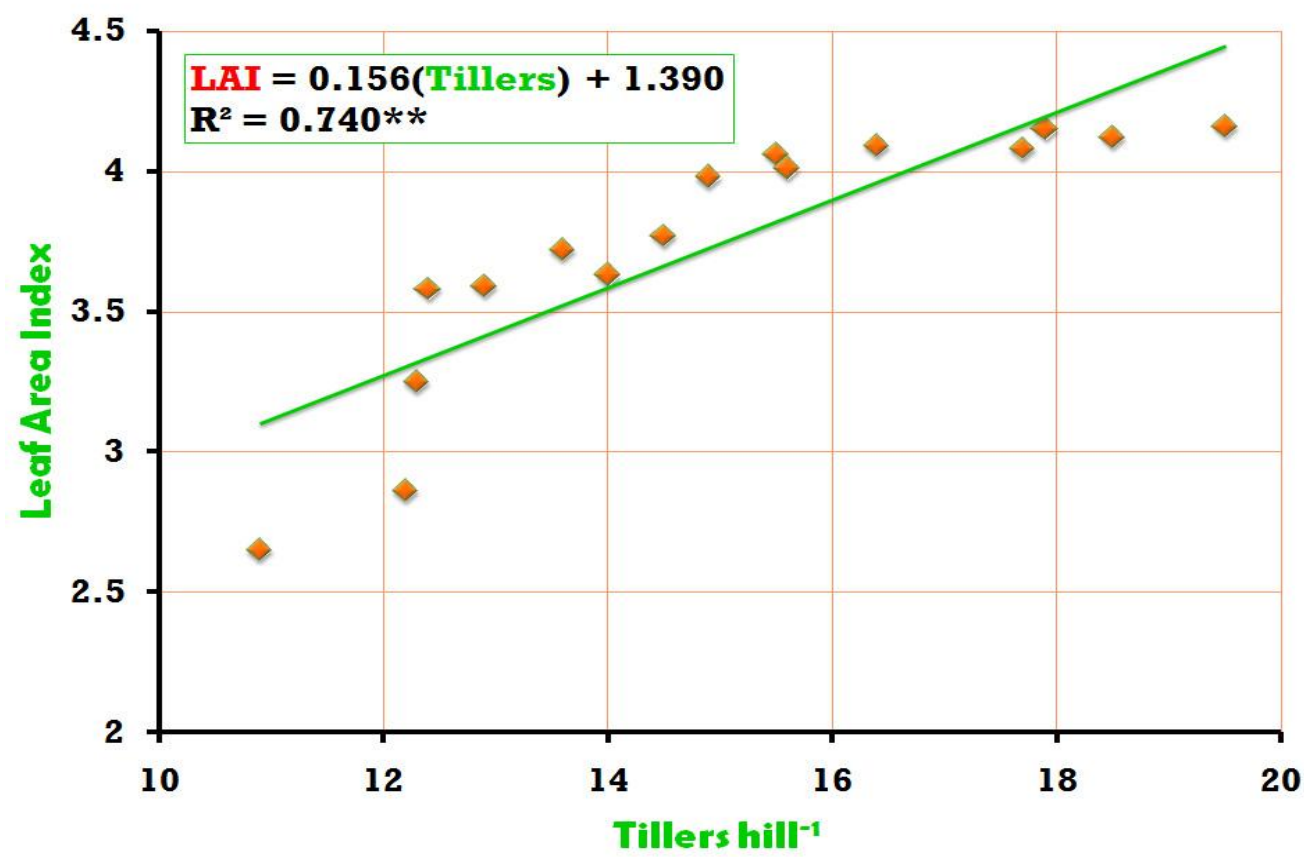

Fig.4 Regression of rice root volume on LAI

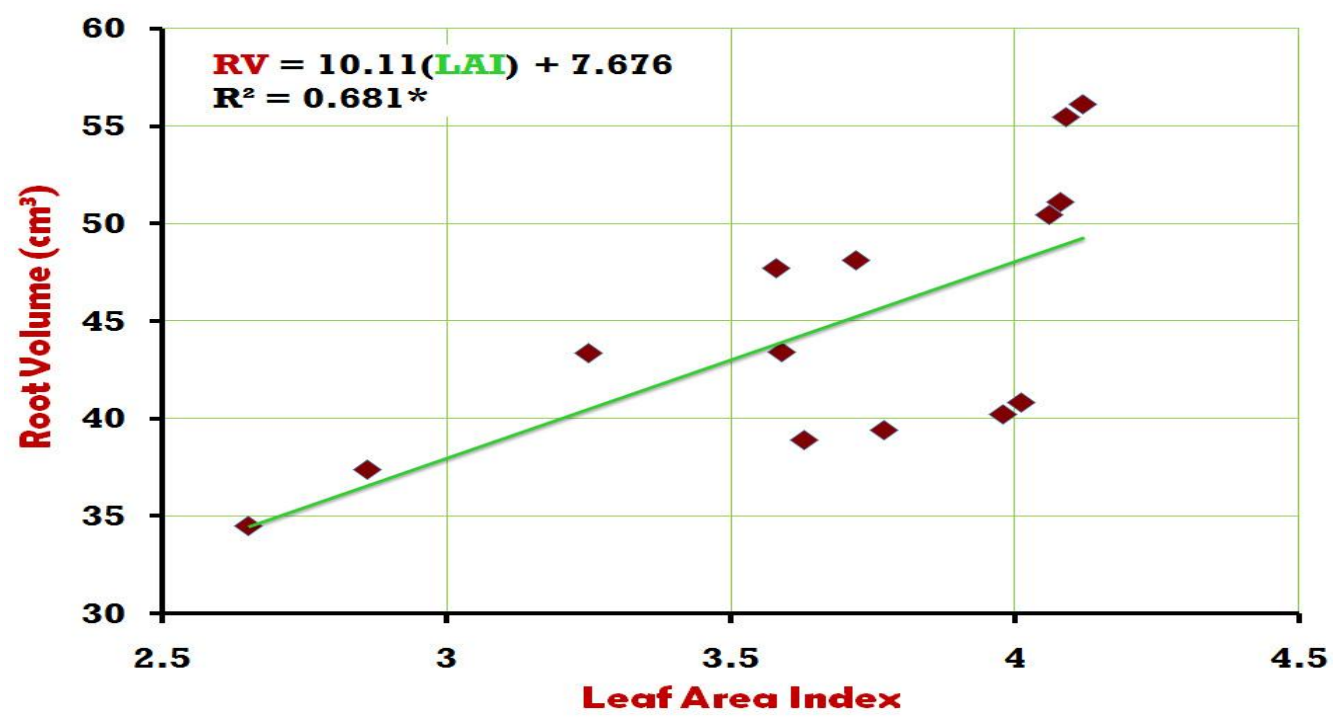


Fig.5 Regression of rice dry matter production on plant height

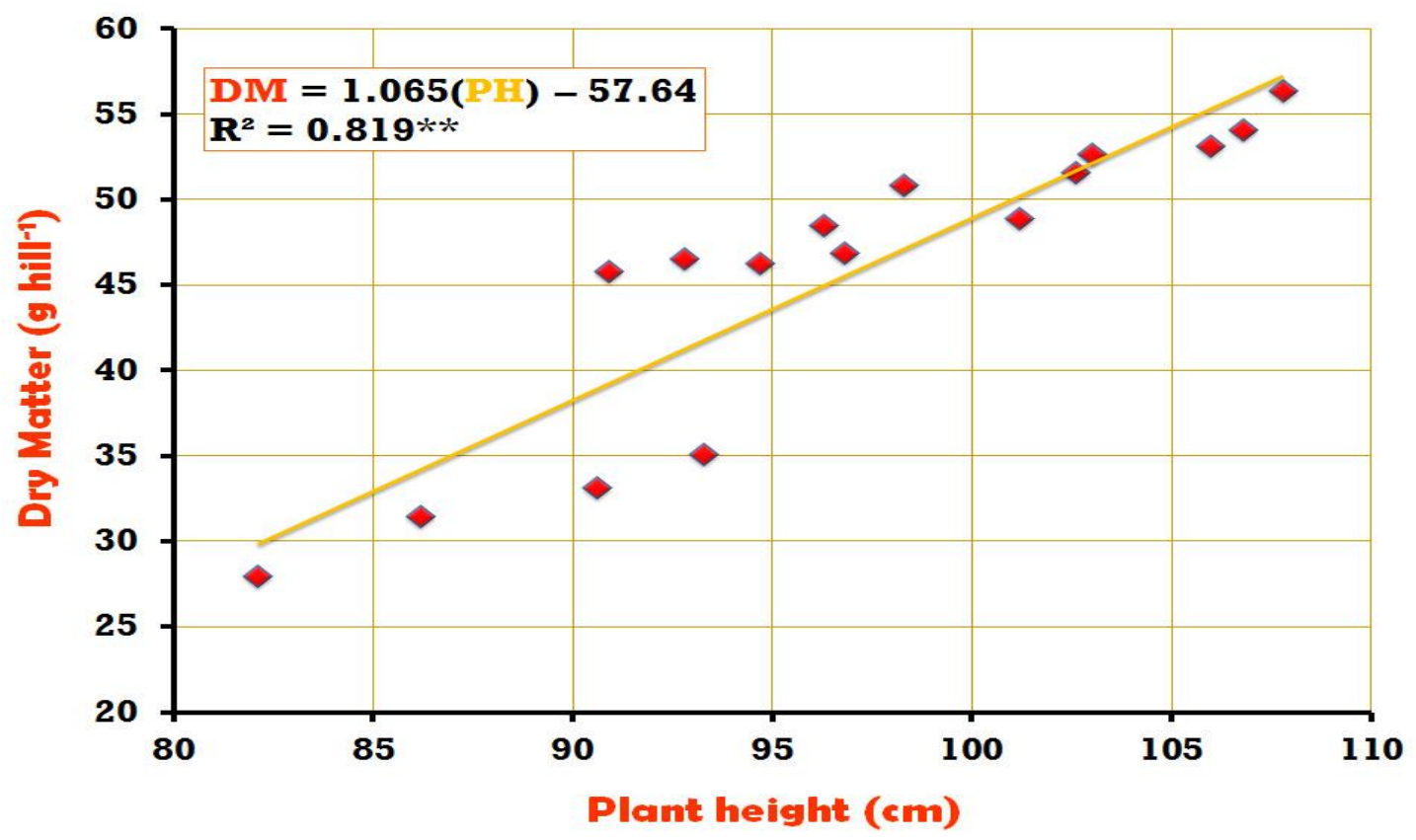

Fig.6 Regression of rice dry matter production on tillers hill-1

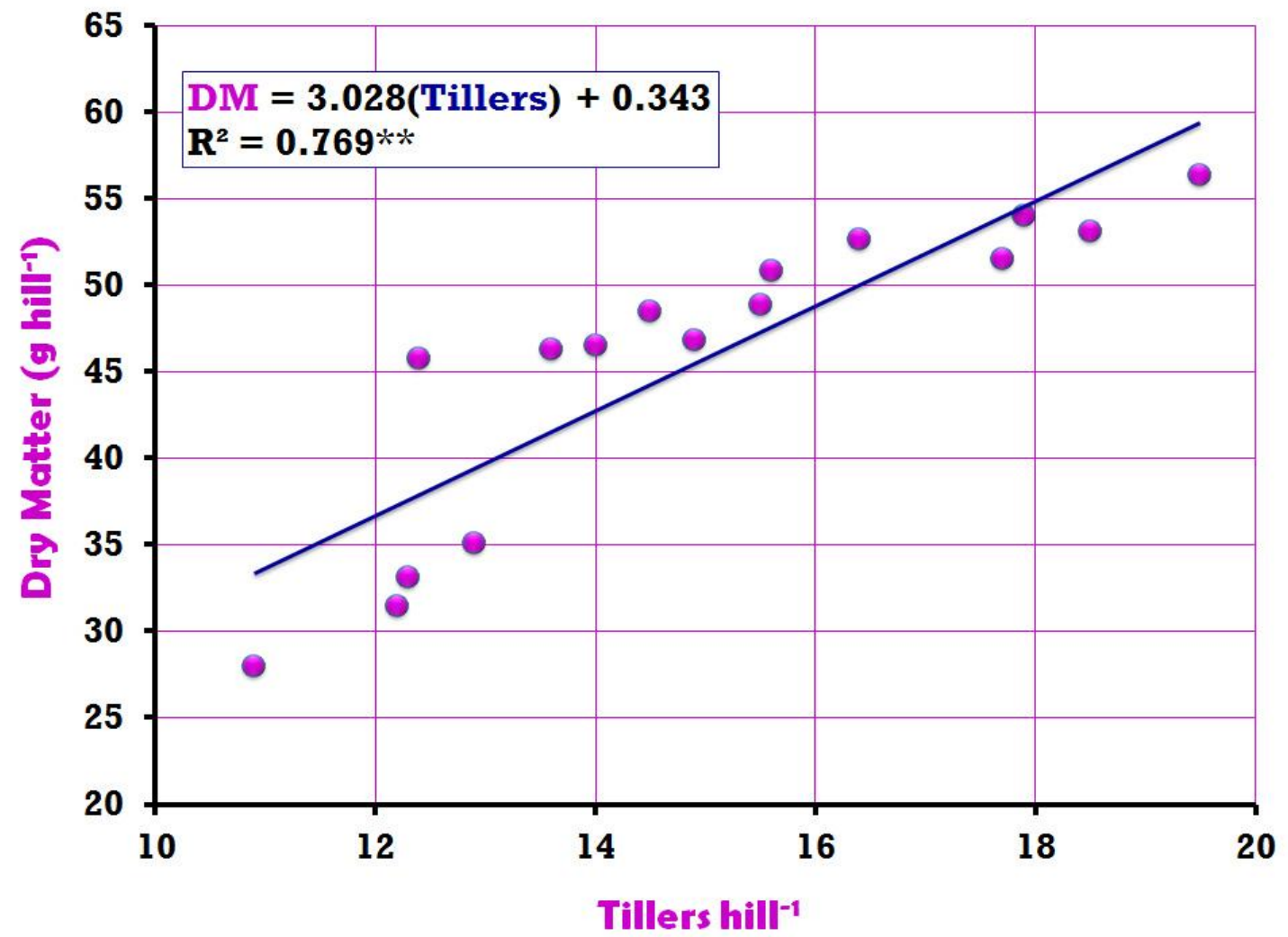


Fig.7 Regression of rice dry matter production on LAI

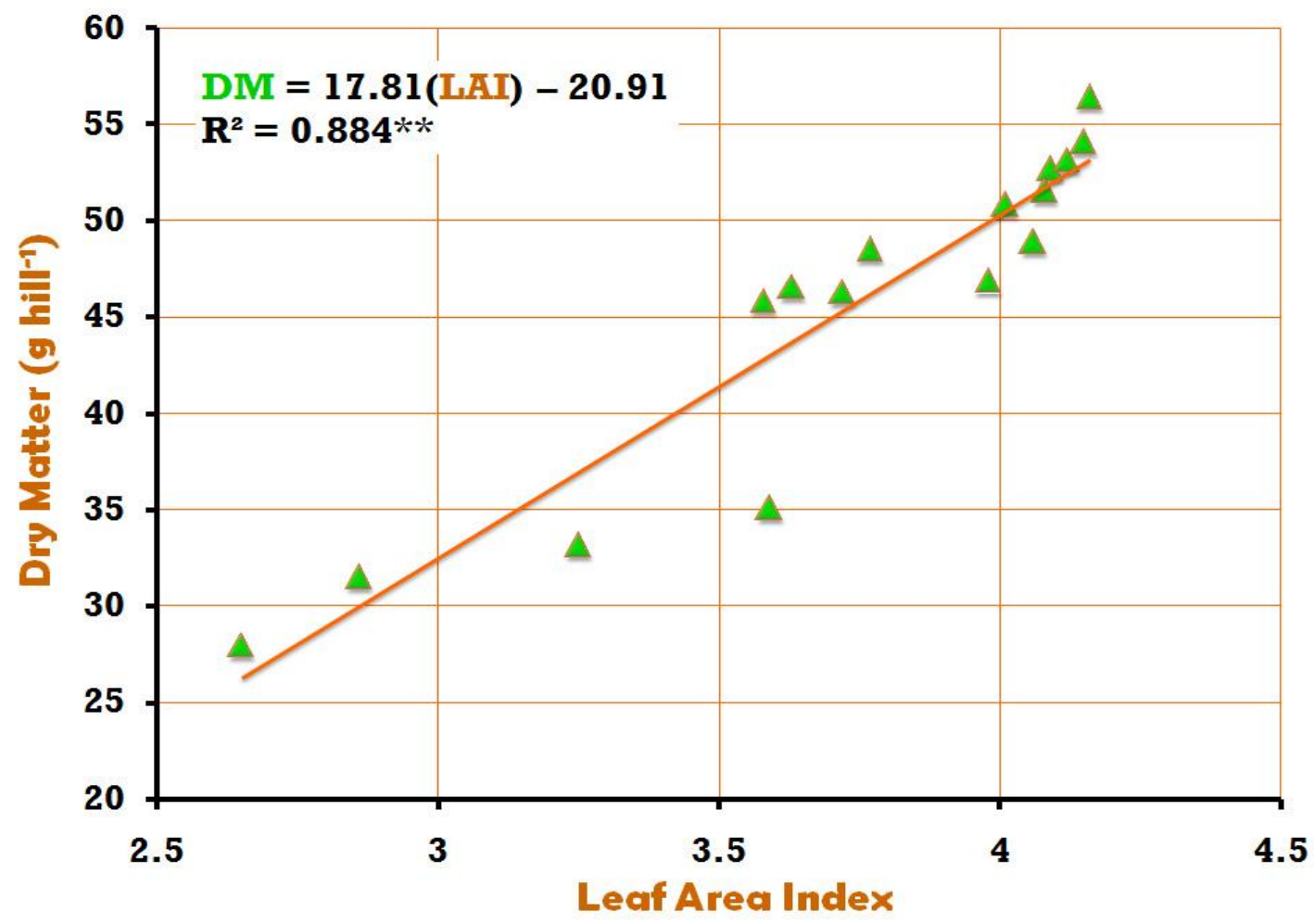

Except that it was statistically on par with $\mathrm{I}_{2}$ (Flooding to a water depth of 3-cm between 15 DAT to PM as and when ponded water level drops to 5-cm BGL in field water tube), $\mathrm{I}_{5}$ (Flooding to a water depth of $5-\mathrm{cm}$ between 15 DAT to PM as and when ponded water level drops to 5-cm BGL in field water tube) and $\mathrm{I}_{6}$ (Flooding to a water depth of $5-\mathrm{cm}$ between 15 DAT to PM as and when ponded water level drops to $10-\mathrm{cm}$ BGL in field water tube) at various crop growth sub-periods in both the years. Among the later treatments although a systematic trend was not registered in terms of dry matter production in different stages and years in general the difference between $\mathrm{I}_{3}$ and $\mathrm{I}_{7}$ and that between $\mathrm{I}_{4}$ and $\mathrm{I}_{8}$ was statistically not significant. Significant lowest dry matter was accumulated in $\mathrm{I}_{4}$ at all growth stages during both the years (Table 5).

The dry matter accumulation in rice is a result of tiller, leaf and stems growth during vegetative phase and a combination of panicle, spikelets and grain weight with concurrent shifts in tiller, leaf and stem mass during reproductive phase (Baligar and Fageria, 2007). Thus it represents not only yield capacity but also average size of photosynthetic organs during succeeding grain filling period and to some extent the amount of carbohydrate reserve accumulated before heading (Murata and Togari, 1972).

Lubis et al., (2013) reported that dry matter production in rice is determined by crop growth rate (CGR) during respective period, and CGR is a function of daily intercepted radiation, radiation use efficiency and leaf area index. Tesfaye et al., (2006) opined that attainment of high LAI that reduces soil water evaporation intercepts and converts radiation into dry matter efficiently. Further the dependence of dry matter production on plant height $\left(\mathrm{R}^{2}=0.819 * *\right.$, Figure 5), tillers hill ${ }^{-1}$ $\left(\mathrm{R}^{2}=0.769^{* *}\right.$, Figure 6$)$, and LAI $\left(\mathrm{R}^{2}=\right.$ $0.884 * *$, Figure 7) was evident from 
significant and positive correlation between them.

\section{References}

Baligar, V.C and Fageria, N.K. 2007. Agronomy and Physiology of tropical cover crops. Journal of Plant Nutrition 30: 1287-1339.

Belder, P., Bouman, B.A.M., Cabangon, R., Lu, G., Quilang, E.J.P., Li, Y., Spiertz, J.H.J and Tuong, T.P. 2004. Effect of water-saving irrigation on rice yield and water use in typical lowland conditions in Asia. Agricutural Water Management 65: 193-210.

Bouman, B.A.M and Tuong, T.P. 2001. Field water management to save water and increase its productivity in irrigated lowland rice. Agricultural Water Management. 49: 11-30.

Bouman, B.A.M., Humphrey, E., Tuong, T.P and Barker, R. 2007. Rice and water. Advances in Agronomy. 92(4): 187-237.

Bumrungbood, J., Hanpattanakit, P., Buddhaboon, C., Rossopa, B and Chidthaisong, A. 2015. Dynamics of rice (Oryza sativa l.) Root and its growth in a heavy clay soil under alternate wetting and drying conditions. Conference: ISC2015 International soil conference: Sustainable uses of soil in Harmony with food security, At The regent Cha Am Beach Resort, Phetchaburi, Thailand.

Chowdhury, M.R., Kumar, V., Sattar, A and Brahmachari, K. 2014. Studies on the water use efficiency and nutrient uptake by rice under system of intensification. The Bioscan 9 (1): 85-88.

Dandeniya, W.S and Thies, J.E. 2012. Rhizosphere nitrification and nitrogen of rice plants as affected by water management. Tropical Agricultural Research 24 (1): 1-11.

Fageria, N.K., Baligar, V.C and Clark, R.B. 2006. Root architecture. In: Physiology of Crop Production. The Haworth Press, Binghamton, NY, USA. pp: 2359.

Gomez, K.A and Gomez, A.A. 1984. Statistical procedures for agricultural research. A Wiley inter science publication, John. Wiley and Sons, New York. p: 680.

Kamoshita, A., Rodriguez, R., Yamauchi, A and Wade, L. 2004. Genotypic variation in response of rainfed lowland to prolonged drought and rewatering. Plant Production Science. 7(4): 406420.

Klemm, W. 1999. Water saving in rice cultivation. In: Assessment and Orientation Towards the 21st Century. Proceedings of 19th Session of the International Rice Commission, Cairo, Egypt, 7-9 September 1998. FAO, Rome, pp. 110-117.

Kobata, T and Takami, S.I. 1983. Grain production and dry matter production in rice in response to water deficits during the whole grain filling period. Japanese Journal of Crop Science 52: 283-290.

Kumar, S., Singh, R.S., Yadav, L and Kumar, K. 2013. Effect of moisture regime and integrated nutrient supply on growth, yield and economics of transplanted rice. Oryza 50 (2): 189-191.

Lockhart, J.A.R and Wiseman, A.J.L. 1988. Introduction to crop husbandry. Wheaton and Company Limited, Pergamon Press, Oxford, United Kingdom.pp: $70-180$.

Lu, J., Ookawa, T and Hirasawa, T. 2000. The effects of irrigation regimes on the water use, dry matter production and physiological responses of paddy rice. Plant and Soil 223: 207 - 216.

Lubis, I., Shiraiwa, T., Ohnishi, M., Horie, T and Inoue, N. 2013. Contribution of sink and source sizes to yield variation among rice cultivars. Plant Production Science 6 (2): 119-125. 
Murata, Y and Togari, Y.1972. Analysis of the effect of climatic factors upon the productivity of rice at different localities in Japan.Proc.Crop.Sci.Soc.Japan. $\quad 41$ : 372-387.

Murata, Y.1967. Studies on the photosynthesis of rice plants and its cultural significance, Dull. National Institute of Agriculture Science. Japan, D9.

Packiaraj, S.R and Venkatraman, N.S. 1991. Influence of irrigation regimes organic amendments and sources of phosphorus on low land rice (Oryza sativa). Indian Journal of Agronomy 36: 14-17.

Pandey, N., Verma, A.K and Tripathi, R.S. 2010. Response of hybrid rice to scheduling of nitrogen and irrigation during dry season. Oryza 47 (1): 34-37.

Peterson, C.M., Klepper, B., Pumphrey, F.B and Rickman, R. W. 1984. Restricted rooting decreases tillering and growth of winter wheat. Agronomy Journal 76: 861-863.

Sandhu, S.S., Mahalb, S.S., Vashist, K.K., Buttar, G.S., Brar, A.S and Singh, M. 2012. Crop and water productivity of bed transplanted rice as influenced by various levels of nitrogen and irrigation in northwest India. Agricultural Water Management 104: 32-39.
Sariam, O and Anuar, A.R. 2010. Effects of irrigation regime on irrigated rice. Journal of Tropical Agricultural and Food Sciences 38 (1): 1-9.

Siopongco, J.D.L.C., Yamauchi, A., Salekdeh, H., Bennett, J and Wade, L.J. 2005. Root growth and water extraction responses of doubled-haploid rice lines to drought and rewatering during the vegetative stage. Plant Production Science 8:497-508.

Tesfaye, K., Walkerb, S and Tsubob, M. 2006. Radiation interception and radiation use efficiency of three grain legumes under water deficit conditions in a semi-arid environment. European Journal of Agronomy 25: 60-70.

Thakur, A. K., Rath, S and Kumara, A. 2011. Performance evaluation of rice varieties under the System of Rice Intensification compared with the conventional transplanting system. Archives of Agronomy and Soil Science 57 (3): 223-238.

Wopereis, M.C.S., Kropff, M.J., Maligaya, A.R and Tuong, T.P. 1996. Droughtstress responses of two lowland rice cultivars to soil water status. Field Crops Research 46: 21-39.

\section{How to cite this article:}

Kishor Mote, V. Praveen Rao, V. Ramulu, K. Avil Kumar, M. Uma Devi and S. Narender Reddy. 2017. Response of Growth Parameters to Alternate Wetting and Drying Method of Water Management in Low Land Rice (Oryza sativa). Int.J.Curr.Microbiol.App.Sci. 6(3): 2081-2097. doi: https://doi.org/10.20546/ijcmas.2017.603.238 